\title{
Analysis of the Educational and Cultural Cooperation Mechanism in the Northwest of China from the Cultural Industry of Silk Road Economic Belt
}

\author{
Wang Shu \\ Xi'an Peihua University \\ Xi'an, Shaanxi, 710125
}

\begin{abstract}
The development and cooperation of cultural industry in Shaanxi Province, Gansu Province, Qinghai Province, Ningxia Province, new five provinces and northwest five provinces in northwest China is an important cooperation field in the strategy of Silk Road Economic Belt. The scale of cultural exchange and cooperation between $\mathrm{Xi}^{\prime}$ an, the five north-west provinces and Middle Asia is very small, which is far from that of other regions. This paper will analyze and discuss the present situation of educational development and educational and cultural cooperation in Northwest China from the Silk Road Economic Belt.
\end{abstract}

Keywords-education cooperation in the northwest of the cultural; industry of the Silk Road Economic Belt

\section{INTRODUCTION}

\section{A. Proposal and Connotation of the Silk Road Economic Belt}

The Silk Road Economic Belt, known as the longest and most potential economic corridor in the world, mainly passes through five provinces in Shaanxi, Gansu, Qinghai, Ningxia and northwest Xinjiang. In his speech in Kazakhstan, Chairman Xi Jinping proposed that cultural industry plays an important role in the economic belt. The development and cooperation of cultural industry in the five provinces of Northwest China is the focus of Silk Road Economic Belt. In "the Dilemma and Development path of higher Education in China" under the background of "Belt and Road Initiative" Strategy, Li Xingyun points out that "the four functions of higher education and their inclusiveness, omnipotence and foresight are the basis of serving the strategy of Belt and Road Initiative. Current higher education faces the dilemma of nonuniversal language talent shortage and low quality of the education." [1]

\section{B. Research Background}

The Silk Road Economic Belt, which connects the AsiaPacific economic circle to the east and the developed European economic circle to the west, is considered to be "the longest and most potential economic corridor in the world." The realization of the strategic conception of the Silk Road Economic Belt will release the great development potential of deep cooperation between China, Central Asia and even South Asia and West Asia, which will further expand China's strategic space for Eurasia. Under the impetus of the upgraded western development strategy, a number of potential urban agglomerations will accelerate the upgrading and conform to the good opportunities for the great development of the western region.

The urban agglomeration of the five northwest provinces along the Silk Road has the cultural advantages, geographical advantages, resource advantages and realistic conditions to build the Silk Road economic belt, which is bound to play a more important role in the Silk Road economic belt. Whether the industrial organization structure of the provinces and autonomous regions along the Silk Road is effective and reasonable will affect the economic development of the Silk Road Economic Belt and even the Silk Road and the radiation zone to a great extent.

\section{To study the significance of educational and cultural cooperation mechanism in Northwest China}

These studies have certain reference significance and value for the research on the competitiveness of cultural industry in the capital of five provinces in Northwest China, but the pertinence is not strong. The main reason is that the scale of cultural exchange and cooperation between Xi'an and even the five northwest provinces and Central Asia is small or even short, and compared with other regions, it is difficult to collect collate and analyze the relevant data. Therefore, it is necessary to find the reasons and breakthroughs from the northwest five provinces themselves. We should first strengthen the cultural industry exchanges and cooperation among the five provinces in the northwest, especially the most fundamental promotion of education and culture. The present paper will analyze and discuss the present situation of education and the cooperation of education and culture in the northwest of Silk Road. 


\section{ANALYSIS OF PRESENT SITUATION OF EDUCATIONAL} DEVELOPMENT IN THE FIVE PROVINCES OF NORTHWEST CHINA

\section{A. Advantages of educational resources in Shaanxi Province(Xi'an)}

Shaanxi is a major educational province and a strong educational province in the western region. Most of the Shaanxi educational resources are concentrated in Xi'an, the capital of the province. Xi'an is the third largest educational city in the country, after Beijing and Shanghai. Since the development of the new western region, the state has invested a lot of manpower, material resources and financial support to improve the educational development of Shaanxi Province. Shaanxi province, as the gateway province for the western development, and Xi'an as the starting city of the silk road economic belt, has abundant educational resources and abundant teachers, and has continuously trained a large number of talents in education, medical and electronic fields for the northwest provinces and regions. Under the call and vision of "Belt and Road Initiative", Shaanxi should do a good job in the development of educational and cultural cooperation among the provinces and regions in Northwest China, make full use of its central geographical position and resource advantages, and promote the steady development of the construction of the Silk Road economic belt. By the end of 2016, there have been 15426 schools in Shaanxi, with 7.518065 million students and 624186 teaching staff. The total number of teachers and students accounted for nearly $1 \%$ of the province's population [4].

\section{B. Status of educational development in the other four provinces of the northwest China (see table 1)}

TABLE I. STATISTICAL TABLE ON THE CURRENT SITUATION OF EDUCATIONAL DEVELOPMENT IN THE OTHER FOUR PROVINCES OF NORTHWEST CHINA

\begin{tabular}{|c|c|c|c|c|c|c|c|c|c|c|c|c|c|c|c|}
\hline \multirow{2}{*}{$\begin{array}{l}\text { eddcation } \\
\text { stage } \\
\text { place } \\
\text { province }\end{array}$} & \multicolumn{3}{|c|}{ preschool education } & \multicolumn{3}{|c|}{ primary education } & \multicolumn{3}{|c|}{ junior high school education } & \multicolumn{3}{|c|}{ High school education } & \multicolumn{3}{|c|}{ higher education } \\
\hline & $\begin{array}{l}\text { school } \\
\text { quantity }\end{array}$ & $\begin{array}{l}\text { be at } \\
\text { school } \\
\text { number } \\
\text { of } \\
\text { people }\end{array}$ & $\begin{array}{l}\text { teacher } \\
\text { quantity }\end{array}$ & $\begin{array}{l}\text { school } \\
\text { quantity }\end{array}$ & $\begin{array}{l}\text { be at } \\
\text { school } \\
\text { number } \\
\text { of } \\
\text { people }\end{array}$ & $\begin{array}{l}\text { teacher } \\
\text { quantity }\end{array}$ & $\begin{array}{l}\text { school } \\
\text { quantity }\end{array}$ & $\begin{array}{l}\text { be at } \\
\text { school } \\
\text { number } \\
\text { of } \\
\text { people }\end{array}$ & $\begin{array}{l}\text { teacher } \\
\text { quantity }\end{array}$ & $\begin{array}{l}\text { school } \\
\text { quantity }\end{array}$ & $\begin{array}{l}\text { be at } \\
\text { school } \\
\text { number } \\
\text { of } \\
\text { people }\end{array}$ & $\begin{array}{l}\text { teacher } \\
\text { quantity }\end{array}$ & $\begin{array}{l}\text { school } \\
\text { quantity }\end{array}$ & $\begin{array}{l}\text { be at } \\
\text { school } \\
\text { number } \\
\text { of } \\
\text { people }\end{array}$ & $\begin{array}{l}\text { teacher } \\
\text { quantity }\end{array}$ \\
\hline $\begin{array}{l}\text { Gansu[5] } \\
\text { (Province) }\end{array}$ & 3971 & 701132 & 30342 & 8052 & 1802401 & 30342 & 1491 & 909255 & 39349 & 386 & 629365 & 27236 & 45 & 450463 & 19494 \\
\hline $\begin{array}{l}\text { Qinghai[6] } \\
\text { (Province) }\end{array}$ & 1667 & 199804 & 10158 & 889 & 457893 & 26408 & 268 & 207937 & 16171 & 106 & 120304 & 8923 & 12 & 61860 & 4340 \\
\hline $\begin{array}{l}\text { Ningxia[7] } \\
\text { (Province) }\end{array}$ & 889 & 206219 & 9445 & 1536 & 582883 & 34116 & 168 & 274696 & 19740 & 43 & 151995 & 10639 & 18 & 121799 & 8044 \\
\hline $\begin{array}{l}\text { Xinjiang }[8] \\
\text { (Province) }\end{array}$ & 5561 & 1086300 & 41800 & 3543 & 2172300 & 146400 & 1613 & 903000 & 84900 & 380 & 552200 & 41100 & 50 & 354400 & 20000 \\
\hline amount to & 12088 & 2193455 & 91745 & 14020 & 5015477 & 284924 & 3540 & 2294888 & 160160 & 915 & 1453864 & 87898 & 125 & 988522 & 51878 \\
\hline
\end{tabular}

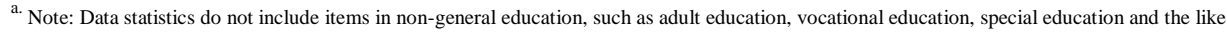




\section{Analysis and Countermeasures for the Development of the Education in the Five Provinces of the Northwest China}

According to the above data, we can see that the educational resources of Shaanxi Province far exceed the other four provinces in Northwest China. As far as the number of schools is concerned, the number of schools in Shaanxi accounts for $32.96 \%$ of the five provinces in Northwest China, including $37.69 \%$ of preschool education, $28.20 \%$ of primary education, $32.33 \%$ of junior middle school education, $34.64 \%$ of senior high school education and $42.66 \%$ of higher education. According to the number of students and teachers in Shaanxi, the average ratio of total students to teachers in Shaanxi is $15 \leq 1$, including pre-school education, primary education, junior middle school education, high school education and higher education, which are $17 \leq 1,15 / 1,10$ / $1,14 / 1$ and $17 / 1$, respectively. The average ratio of total students to teachers in the province is $18 \leq 1$, including 21 in preschool education, 18 in primary education, 14 in junior middle school, 17 in senior high school and 19 in higher education. Thus it can be seen that the educational resources at all levels in Shaanxi, including the number and scale of schools, the proportion of students and teachers, the number of full-time teachers, show a large leading trend. Shaanxi (Xi'an) should take the lead in using its own rich educational resources and strong teacher strength, take various forms to lead the other four provinces to enhance the soft power of education, build educational platforms jointly, share educational resources and seek the great development of education.

\section{DISCUSSION ON THE ESTABLISHMENT OF EDUCATIONAL AND CULTURAL COOPERATION MECHANISM IN THE FIVE PROVINCES OF Northwest China}

The so-called "educational cooperation mechanism" is a series of rules and procedures that come into being in the interdependence of education, aggregate with the expectations of the participants, and can control the results of behavior [2]. According to the above data analysis, Shaanxi Province (Xi'an City) has obvious advantages in educational development in Northwest China, so it has the ability to lead and drive, but there are still some problems to be discussed in the process of establishing regional education cooperation mechanism.

\section{A. Core issues — Talent issues}

Belt and Road Initiative strategy not only covers the support of regional infrastructure construction, but also includes regional capital, the formation of political and strategic order, and the improvement of regional governance. Capital, capacity, technology, ideas and policies, trade, currency connectivity all need talent input and think tank support. The demand for talents in the construction of the Silk Road Economic Belt must be borne by Chinese education.

Northwest China, as the hinterland of the Silk Road on land, has a strong demand for talents. In order to alleviate the pressure on talents, we need to adjust the purpose of higher education training as soon as possible. On the one hand, relying on Shaanxi Province, the technical talents of colleges and universities in Shaanxi-Gansu region will be transported to the western or surrounding countries in urgent need of development to experience, obtain employment, and establish a win-win relationship of cooperation. On the other hand, attract foreign students from neighboring countries to study in Shaanxi, establish "go out, please come in" and other talent exchange mechanisms to create higher education with Shaanxi characteristics.

\section{B. Establishment and Prospect of Educational and Cultural Policies in the Five Provinces of Northwest China}

Since the "cultural power" of the 18th century, how to adapt to the development of the economic belt of the Silk Road in the field of education and culture has become a new focus in this field.

The provinces and cities on the Silk Road economic belt are mutually beneficial. In order to achieve a win-win situation between the two stakeholders, we must formulate corresponding policies and systems to restrain both sides. Shaanxi Province (Xi'an City) occupies great advantages in northwest China, both in geographical position and in terms of educational resources. As the gateway to the great development of the new western region of China, as the starting point of the Silk Road economic belt, Shaanxi Province (Xi'an City) should play a helping role in the promotion of education in other provinces and cities in Northwest China, and play a leading role in the development of education in other provinces and cities. For example, Northwestern University and Xi'an Jiaotong University can help Yinchuan University to carry out double guidance of teaching and scientific research; Shaanxi normal University, Northwest University of Agriculture and Forestry Science and Technology can run schools jointly with Urumqi University; Xi'an Jiaotong University and Northwest University of Technology can exchange visits with Lanzhou colleges and universities to educate co-education talents. Xi'an University of Electronic Science and Technology, Chang'an University can guide Xining University to do technical research and development according to local conditions, and Xi'an Foreign Studies University can also carry out language and cultural exchanges with Xinjiang and Ningxia universities.

\section{The mode of educational and cultural cooperation mechanism and the type of transmission and help}

In addition to the government-led and free cooperation model put forward by Professor Kang Chen and other professors, I think the most suitable mode of educational and cultural cooperation in Northwest China should be the mode of communication and help. The mode of educational cooperation mainly combines the differences of economic development in different regions and takes a certain region as the dominant area to promote the development of the surrounding provinces and cities. Only with the difference of regional educational resources can we highlight the role of the cooperative model of communication and support education. The differences among other provinces and cities in northwest China and Shaanxi Province (Xi'an City) are mainly caused by different economic development, educational facilities, educational investment and the development of teachers. To 
balance the difference of educational resources in the northwest area, we should be more and more favorable for the construction of the economic belt of the Silk Road.

\section{CONCLUSION}

The establishment of educational cooperation mechanism is for a better and faster development of provinces and cities in the region, and to realize the mutual benefit and win-win of the main body of cooperation. School-school cooperation can better promote the deep cultivation of talents and the sharing of excellent resources, and school-enterprise cooperation can provide effective channels and opportunities for students' practical ability and scientific research direction, and avoid the separation of theory from reality. In order to effectively realize mutual benefit in the process of cooperation, we must formulate a set or a series of express or implied principles, norms and policies. The main types of educational cooperation rules are negotiation rules, execution rules, coordination rules, explicit rules, implicit rules, normative rules, procedural rules, etc [3]. These rules restrict the cooperation of the two parties in the process of cultural cooperation in the northwest of China, and ensure the orderly progress of the educational and cultural cooperation of the provinces and cities in the northwest region.

\section{REFERENCE}

[1] Li Xingyun. Difficulties and Development Path of Higher Education in China under the Background of "Belt and Road" . Journal of Nanjing University of Technology(Social Science), 2016.

[2] Kang Chen, et al. A study on the Construction of Educational Cooperation Mechanism of Silk Road Economic Belt [J]. Theoretical Exploration, 2014

[3] Tang Xiaoping. A theoretical Analysis of the Mechanism of International Educational Cooperation [J]. Journal of Guangxi normal University, 2004 (4)

[4] Website of Shaanxi Provincial Department of Education: http://www.snedu.gov.cn/about/jygk.html.

[5] Website of the Department of Education of Gansu Province: http://www.gsedu.gov.cn/content-xxgk_1645.htm.

[6] Department of Education of Qinghai Province: http://www.qhedu.cn/zwgk/jygk/201704/t20170406_23579.html.

[7] Website of Education Department of Ningxia Hui Autonomous region: http://www.nxedu.gov.cn/sviewp/FF6328B0-827C-4676-889E6B02D41AE19E.

[8] Website of Education Department of Xinjiang Uygur Autonomous region: http://www.xjedu.gov.cn/xjjyt/sytj/2017/104581.htm. 